\title{
On the exceptional status of reportative evidentials*
}

\author{
Scott AnderBois \\ Brown University
}

\begin{abstract}
One of the central questions in the study of evidentials cross-linguistically is to what extent (and in what ways) evidentials differ across languages and across evidence types. This paper examines one such instance of variation: the ability for a single speaker to deny the scope of a reportative evidential, an instance of what we dub 'Reportative Exceptionality' (RE). Empirically, we show that RE is widely attested across a diverse range of reportatives. Theoretically, we propose a pragmatic account treating RE as an instance of pragmatically-induced perspective shift. Having done so, we propose a semantics for illocutionary evidentials on which reportatives are given a treatment uniform to other evidence types.
\end{abstract}

Keywords: evidentiality, reportatives, perspective shift, assertion

\section{Introduction}

Evidentials are functional morphemes which, when occurring in declarative sentences, encode the information source associated with a given claim, as in (1):

\section{Tariana}

Juse irida di-manika- $\{\varnothing / \mathbf{m a h} / \mathbf{n i h} / \mathbf{s i} / \mathbf{p i d a}\}-\mathrm{ka}$.

José football 3sg-play-\{ vis/nonvis/infer/assum/rep $\}$-REC.PAST

$p=$ 'José has played football.'

EVID $=$ Speaker saw/heard/inferred/assumed/was told that $p$.

While not all authors phrase the intuition in this way, I take the 'Baseline Conception (BC)' in (2) to be a fairly uncontroversial, if imprecise, pretheoretical description of the typical use of evidential-marked declaratives:

* Many thanks to John Haviland, Polly Jacobson, Lauri Karttunen, Laura Kertz, Greg Kierstead, Loes Koring, Sarah Murray, Mark Norris, Craige Roberts, Wilson Silva, Juan Jesús Vázquez Álvarez, 5 anonymous SALT reviewers, and audiences at (Re)presenting the Speech of Others at the University of Groningen, Brown University, and SALT 24 for helpful discussion of the ideas here. Thanks also to Lauri Karttunen, Mark Norris, Anastasia Smirnova, and Juan Jesús Vázquez Álvarez for data reported here for Finnish, Estonian, Russian, and Chol respectively. 
On the exceptional status of reportative evidentials

(2) BASELINE CONCEPTION of Evidentials:

A speaker who sincerely utters a declarative sentence $p_{\text {EVID }}$ with propositional content $p$ and an evidential of type EVID typically:

a. Performs an assertion with content $p$ (or a modalized version thereof).

b. Conveys in some way that the speaker has EVID-type evidence that $p$.

As should be clear from the use of terms like 'sincerely utter', this definition is of course at the level of use and is therefore a characterization of the pragmatics of evidentials. However, the question naturally arises of what parts of this picture are conventionally encoded (i.e. are semantic). More specifically, to what extent does the contribution of evidentials within and across languages match the Baseline Conception? This paper examines what we will show to be a systematic counterexample to the BC: the exceptional status of reportatives.

The exception: The first part of the Baseline Conception, (2a), leads us to expect that it should be infelicitous for a speaker to deny $p$ immediately after uttering an evidential-marked sentence $p_{\text {EVID }}$. As first discussed in detail by Faller (2002) for Cuzco Quechua, this expectation is not upheld, an instance of what we will call 'Reportative Exceptionality' (RE).

\section{(3) Cuzco Quechua}

(Faller 2002: 191)

a. Pay-kuna- $s$ ñoqa-man-qa qulqi-ta muntu-ntin-pi saqiy-wa-n

(s)he-PL-REP I-ILLA-TOP money-ACC lot-INCL-LOC leave-1O-3

$p=$ 'They leave me a lot of money'

$\mathrm{EVID}=$ Speaker was told that $p$.

b. mana-má riki riku-sqa-yki ni un sol-ta centavo-ta-pis saqi-sha-wa-n-chu. not-IMPR right see-PP-2 not one sol-ACC cent-ACC-ADD leave-PROG-1O-3-NEG $q=$ '(but) that's not true, as you have seen, they don't leave me one sol, not one cent.'

$\mathrm{EVID}^{1}=$ Speaker has direct evidence that $q$.

Addressing the exception: Faller (2002) and previous authors who have provided accounts of such data have been unanimous in building this exceptional status into the semantics of the REPORTATIVE, thereby denying that REPORTATIVES fit (2) even at the level of compositional semantics. For example, Faller (2002) claims $p$ is not asserted in (3a), but merely 'presented', in contrast to other evidentials in the language.

1 Faller argues that sentences in Cuzco Quechua without an overt evidential implicate that the speaker has direct evidence. The evidence for $q$ in this example, then, has a different status than the evidence for $p$. 
In this paper, we argue that, contrary to suggestions in prior literature, the potential for examples analogous to (3) is extremely widespread cross-linguistically, extending across languages whose reportatives and evidential systems more generally differ in numerous other ways (N.B. this is not to say that such cases are typical or frequent in any language). Given this more uniform empirical picture, we propose a pragmatic account of (3) and similar data cross-linguistically as case of pragmatic perspective shift, drawing on Harris \& Potts's (2009) account of the perspectival orientation of expressives and appositives in English. Such perspective shift arises only in reportatives since they introduce another perspectival agent, whereas other evidentials do not. Beyond explaining why only reportatives are exceptional in this way, the proposal explains the forms that denials like (3b) typically take. Finally, having argued that RE is pragmatic in nature, we provide a unified account of the meaning of REPORTATIVE, DIRECT, and ABDUCTIVE INFERENTIAL illocutionary evidentials in declaratives.

\section{Reportative exceptionality}

\subsection{Typology of evidentials}

Before examining reportative exceptionality in detail, we first provide a bit of context regarding the landscape of evidentiality more generally. The most common typology of evidentials is due to Willett (1988), who distinguishes the types of information source encoded by evidentials cross-linguistically as in (4).

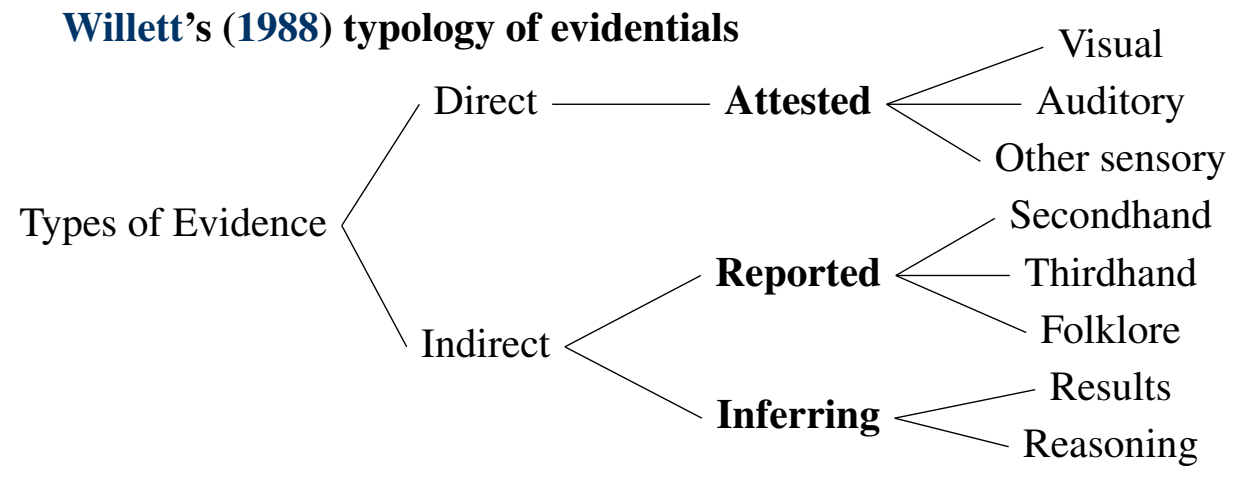

While much of the literature on evidentials stress that they convey information source and not certainty, there nonetheless exist intuitive relationships between the two. If someone tells me that it is raining, but my direct visual evidence contradicts this, I will presumably trust my direct visual evidence over this secondhand report, no matter how trustworthy I find the reporter to typically be. Indeed, Faller (2012) argues for Cuzco Quechua that a quantity implicature-like inference can arise in certain cases where a speaker uses the reportative -si in place of the intuitively 
On the exceptional status of reportative evidentials

stronger direct competitor, -mi. Finally, it has been suggested by various authors that there exist universal hierarchies of evidential strength on which reportatives are lowest (Attested $>$ Inferring $>$ Reported).

Could it be then that reportative exceptionality stems from reportative evidence being in some sense 'weaker' than other kinds of evidence? In a word, no. First, other authors including Willett (1988) have proposed conflicting scales where reportatives are not the weakest (Attested $>$ Reported $>$ Inferring). Second, these scales have been proposed primarily based on the metalinguistic intuitions of native speakers and linguists, rather than grammatical evidence. The implicatures discussed by Faller (2012) might provide empirical support the existence for two subscales (Direct $>$ Reported and Direct $>$ Inferring), but give no evidence for any relative ordering between Reported and Inferring evidentials. Finally, Faller (2002: §2.4) argues persuasively against any fixed ordering, noting that context and the propositional content of the scope proposition determine what information source is 'strongest'. One very clear kind of evidence for this are propositions whose content concerns the internal mental states of others, such as $p=$ 'Maribel wants to go to São Paulo this summer.'. Here, it seems clear that a report from Maribel (or even some third party) will be an intuitively 'stronger' information source for $p$ than direct visual evidence of Maribel's mental state possibly could be. ${ }^{2}$

We conclude, therefore, that to the extent that there even exist fixed 'strength' relationships between different evidentials, there is no reason to think that reportative exceptionality can be do to the inherent 'weakness' of reportative information sources.

\subsection{The exceptional status of reportatives}

Having placed reportatives within the larger typology of evidentials, we turn now to examining the exceptional status of reportative evidentials. As noted in the introduction, the Baseline Conception in (2) holds that the 'scope proposition' $p$ is asserted. Given this, we expect that an utterance of the form ' $p_{\mathrm{EVID}}$ and $\neg p$ (DIR)' should be infelicitous, ${ }^{3}$ just like non-evidential utterances of ' $p$ and $\neg p$ '. Moreover, we predict that this should be so regardless of what values EVID takes here and whether or not they include a possibility or necessity modal.

2 Given this, it seems reasonable to question whether even the two subscales mentioned above are empirically warranted or if such scales instead emerge from case-by-case reasoning about what kinds of evidence would be strongest for a given proposition in a given context.

3 The parentheses indicate that variability in whether or not an overt evidential is needed in the second conjunct. Related to this concern is the question of whether sentences with no overt evidential have a phonetically null DIRECT evidential, conversationally implicate a DIRECT evidential value, or neither. We set this aside here since they run equally afoul of the BC. 
Contrary to this expectation, however, we consistently can find examples of the form ' $p_{\mathrm{REP}}$ and $\neg p$ (DIR)' across languages. We present a couple such examples here and refer the reader to the Appendix for further such examples from more than 20 languages.

\section{Chol} (Juan Jesús Vázquez Álvarez (p.c.))

am- $\varnothing=$ bi juñ-tyiki mach-bä ba' añ- $\varnothing$ tyi pul-i- $\varnothing$, jiñ-jach E-B3=REP one-CL NEG=REL where E-B3 PRFV burn-IV-B3 PRON3=only che' mach melel, tsä'-äch lu' pul-i-y-ob.

that NEG true PRFV=AFFR all burn-IV-EP-PL3

'It is said that there was one (person in the airplane) that didn't burn up, but it's not true, they all burned.'

(6) Estonian

(Mark Norris (p.c.))

Ta küll ole -vat aus mees, aga ta ei ole üldse aus. he surely be-REP honest man but he NEG be at.all honest 'It's certainly been said that he is an honest man, but he's not honest at all.'

\section{Finnish}

(Lauri Karttunen (p.c.))

Liisa on kuulemma jo lähtenyt, mutta en usko näin

Liz is REP already left but not believe like.this

'I've heard that Liz has already left, but I don't believe it.'

\section{Tagalog}

(Schwager 2010: 237)

Dadating daw siya sa isang oras, pero hindi talaga.

will.come REP he in one hour but not really

'He says he will come in an hour, but in fact he won't.'

Before continuing, we must note that there is one putative exception to the pattern discussed here: Matthewson, Davis \& Rullman's (2007) work on St'át'imcets. We examine the data from St'át'imcets and two other languages of the Pacific Northwest in detail in $\S 3.4$, but mention it here since this data has led previous authors to regard $\mathrm{RE}$ as a point of significant cross-linguistic variation in reportatives. ${ }^{4}$

Beyond being attested in a fairly large number of unrelated languages across different linguistic areas, examples of this sort are found across languages whose reportatives differ in a great many different ways, outlined in Table 1. Of particular interest is that such examples are robustly attested even in languages where they have been analyzed as epistemic modals. Following Matthewson et al. (2007),

4 Krawczyk (2012: 90) provides an especially clear statement of this claim, claiming a 'Taxonomy of Reportative Evidentiality' whose primary division is between those languages where reportatives are 'exceptional' in our terms and those where they require speaker commitment. Alongside St'át'imcets, Krawczyk mentions only German, despite the examples discussed by Mortelmans (2000) and Schenner (2010). 
On the exceptional status of reportative evidentials

\begin{tabular}{|l|l|}
\hline \multicolumn{2}{|l|}{ REPORTATIVE is part of larger evidential paradigm? } \\
\hline Yes & Central Alaskan Yup'ik, Cheyenne, Cuzco Quechua \\
\hline No & Chol, Dutch, German, Russian, Tagalog, Tojolab'al \\
\hline REPORTATIVE is analyzed as: \\
\hline Epistemic Modal & Bulgarian, Dutch, German, Japanese, Turkish \\
\hline Illocutionary operator & Central Alaskan Yup'ik, Cheyenne, Cuzco Quechua \\
\hline Other & Tagalog, Korean, Paraguayan Guaraní \\
\hline Morphosyntactically, REPORTATIVE is described as: \\
\hline Verbal affix & Bulgarian, Estonian, Korean, Turkish \\
\hline Clausal Clitic & Chol, Cuzco Quechua, Paraguayan Guaraní, Tojolab'al \\
\hline Auxiliary & German, Dutch \\
\hline Particle & Finnish, Russian, Tagalog \\
\hline REPORTATIVE must take widest scope? \\
\hline Yes & Central Alaskan Yup'ik, Cheyenne, Chol, Cuzco Quechua \\
\hline No & German, Japanese, Tagalog \\
\hline
\end{tabular}

Table 1 Diversity of reportatives allowing denials

recent literature has taken the potential for RE to be a property of a certain type of evidential. The pervasiveness of RE across different sorts of languages seen here, however, seems most consistent with a view of RE as an extremely robust cross-linguistic pattern, rather than one limited to reportatives of a particular kind. ${ }^{5}$

In contrast to reportatives, other evidentials - both direct and indirect - are consistently infelicitous in parallel examples even within these same languages. We might be tempted to think of the infelicity of parallel examples with direct evidentials as in (9) as being a reflex of the apparent certainty of direct evidence. However, no such explanation is tenable for other sorts of evidentials such as conjecturals and abductive inferentials, as in (10-11). It is at least as plausible in principle for a speaker to have abductive inferential or conjectural evidence that $p$, yet assert $\neg p$, as it would be in the case of reportatives (c.f. 'It seems like she left, but she didn't').

\section{Cheyenne}

\#É-hótȧheva- $\varnothing$ Floyd naa oha é-sáa-hótȧhévá-he- $\varnothing$.

3-win-DIR.3sg Floyd and CNTR 3-neg-win-MOD $a$-DIR

'Floyd won, I'm sure, but I'm certain he didn't.'

5 Conversely, it should be noted that given the pragmatic account of RE we propose in $\S 3$, the existence of such data does not give any clear argument for or against a modal analysis for these languages. 
(10) Cuzco Quechua

(Faller 2002: 163)

\#Llave-qa muchila-y-pi= chá ka-sha-n ichaqa mana-n aqhay-pi-chu. key-TOP bag-1-LOC-CONJ be-PROG-3 but not-DIR there-LOC-NEG \#'The keys maybe/are possibly/probably in my backpack, but they are not there.'

(11) Central Alaskan Yup'ik

(Krawczyk 2012: 22)

\#Aya-llru-llini-uq, $\quad$... aya-ksaite-llru-yuk-aa.

leave-PAST-INFER-IND. $3 \mathrm{SG} \ldots$ leave-NEG-PAST-think-IND. $1 \mathrm{SG}_{s} \cdot 3 \mathrm{SG}_{o}$ \#'Evidently she left ... [but] I don't think that she left.'

In summary, we find that cross-linguistically it is (at least) nearly universal that an evidential-marked claim can be felicitously denied by the same speaker only if its evidence type is reportative.

\subsection{Semantic accounts of reportative exceptionality}

While the cross-linguistic systematicity of RE has gone unrecognized, there are several accounts of RE within particular languages. Common to all of these accounts is that they treat $\mathrm{RE}$ as part of the conventional contribution of the reportative morpheme, i.e. its compositional semantics.

The earliest such account is Faller's (2002) account of the Cuzco Quechua reportative -si. Faller's (2002) approach to evidentials in general is to claim that all evidentials in the language are speech act modifiers (i.e. functions from speech acts to speech acts). For the reportative -si, Faller (2002) proposes the function in (12) as its conventional contribution. The input, on the left side, is what Faller takes to be the contribution of an ordinary (i.e. non-evidential) assertion. The output, on the right side, is the contribution of the reportative-marked assertion.

$$
\begin{aligned}
& \text { Faller's (2002) semantics for Cuzco Quechua -si: } \\
& \operatorname{AsSERT}(p) \rightarrow \operatorname{PRESENT}(p) \\
& \operatorname{SinC}=\{\operatorname{Bel}(s, p)\} \rightarrow \operatorname{SinC}=\left\{\exists s_{2}\left[\operatorname{Assert}\left(s_{2}, p\right) \wedge s_{2} \notin\{h, s\}\right]\right.
\end{aligned}
$$

This function, then, contributes two things. First, it replaces the default sincerity condition that the speaker believes that $p$ to one where someone else has asserted that $p$. Second, it changes the essential condition of the speech from an assertion to a new speech act, which Faller dubs a 'Presentation'. The first component encodes the information source as being reportative while capturing the fact that it is separate from the main propositional content. This part of the reportative's meaning is roughly parallel to other evidentials, differing only in the type of information source referred to. The second part, however, is where the exceptional status of reportatives 
On the exceptional status of reportative evidentials

is located, since the speaker merely presents the content of the report rather than asserting it.

Murray (2010) makes use of an update semantics which allows for a compositional account of the roles of declarative/interrogative mood and evidentials in producing a particular series of updates. While this approach builds on Faller's in many important ways, the account of RE is essentially the same. The reportative's conventional contribution creates an update proposing "to take note of the at-issue proposition, ... but for the common ground to remain unchanged". While it is not a priori implausible that RE would be semantic in nature, its pervasiveness across reportatives whose semantics differ in various other ways suggests that we might hope to derive it from more general pragmatic principles.

\section{A pragmatic alternative}

In this section, we develop a pragmatic account of RE based on the notion of pragmatic perspective shift of the sort proposed by Harris \& Potts (2009) to account for non-speaker-orientation of English appositives and expressive epithets.

\subsection{Pragmatic perspective shift}

It is, of course, well known that material in the complement of attitude verbs like English think and believe is ordinarily attributed to the subject of that verb. For example, Mary's being an alien in (13) is attributed to John, not the speaker. ${ }^{6}$

(13) John thinks that Mary is an alien.

Certain kinds of semantic content, however, have been claimed to be invariably attributed to the speaker, even in attitudinal complements. For example, Potts 2005 (and references therein) proposes a semantics where appositive relative clauses and expressive epithets are uniformly speaker-oriented:

(14) I disagree with the expert who advised the Carnegie family that the father, who is not the breadwinner, does not need life insurance. (COCA, Davies 2008-)

While such speaker-orientation is typical of appositives and expressives, subsequent authors have claimed that non-speaker-orientation is in fact possible. Consider, for example, the following examples from Amaral, Roberts \& Smith 2007. Given that the speaker in (15) has distanced herself from the whole of Joan's story, it is

6 One well-known exception, of course, is the descriptive content of $d e$ re attitude reports. See Faller (2002: §6.3.5) for discussion of parallel data with reportative evidentials. 
quite clear that it can only be Joan and not the speaker who has opinions about the installation date of the brain chip.

(15) Joan is crazy. She's hallucinating that some geniuses in Silicon Valley have invented a new brain chip that's been installed in her left temporal lobe and permits her to speak any of a number of languages she's never studied. She believes that, thoughtfully, they installed a USB port behind her left ear, so the chip can be updated as new languages are available. Joan believes that her chip, which she had installed last month, has a twelve year guarantee.

Rather than arguing against a speaker-oriented semantics, Harris \& Potts (2009) argue that these examples are due to pragmatically-driven perspective shift. The clearest support for this claim is that non-speaker-orientation is possible even in unembedded cases, provided that the environment is 'perspectivally-rich'.

(16) I was struck by the willingness of almost everybody in the room - the senators as eagerly as the witnesses - to exchange their civil liberties for an illusory state of perfect security. They seemed to think that democracy was just a fancy word for corporate capitalism, and that the society would be a lot better off if it stopped its futile and unremunerative dithering about constitutional rights. Why humor people, especially poor people, by listening to their idiotic theories of social justice? (Lewis Lapham, Harper's Magazine, July 1995)

They show through experimental and corpus work that the salience of another perspectival agent in the context is the key factor allowing for non-speakerorientation of appositives and expressives, rather than any particular syntactic configuration. They do find that being embedded under a third-person attitude verb helps (indirectly) promote non-speaker-orientation as well, since it brings to salience the attitudinal subject's perspective. However, such embedding is neither necessary nor sufficient for non-speaker-oriented interpretations to arise. Summing up, we conclude that certain kinds of otherwise speaker-oriented content can be attributed to other perspectival agents in 'perspectivally-rich' contexts.

\subsection{Reportative exceptionality as perspective shift}

In this section, we argue that $\mathrm{RE}$ as in (17) arises from a pragmatic perspective shift of the same sort.

(17) Cheyenne

É-hótảheva- sėstse Floyd naa oha é-sáa-hótảhévá-he- $\varnothing$.

3-win-REP.3sg Floyd and CNTR 3-neg-win-MOD $a$-DIR

'Floyd won, I hear, but I'm certain he didn't.' 
On the exceptional status of reportative evidentials

In line with the Baseline Conception, we assume that the conventionally encoded discourse effect of the reportative-marked clause in (17) is as follows: ${ }^{7}$

a. Speaker asserts (in some sense) that $p$

b. Speaker conveys that their evidence for $p$ is what someone else has told them

However, the second part of the conventional contribution of the reportative, (18b), makes salient a non-speaker perspective: that of the reporter. This, in combination with a sufficiently rich context, allows (18a) to be attributed not to the reporter rather than the speaker, just as Joan's chip installation date is attributed to a non-speaker perspective in (15). We use the term 'context' here in the broadest sense, including world knowledge about the speaker's beliefs, the speaker's presumptions about the hearer's perspective on these, as well knowledge about the perspective of the contextually salient reporter including his/her reliability.

Crucial to establishing such context in many of the attested examples is the presence of other linguistic elements which serve to make the disconnect between the speaker's perspective and the reporter's publicly clear. Specifically, we observe that the denials in examples in (5-8) (and similar examples in the Appendix) typically make use of words translatable with English really, actually, or true, first person attitude reports, negative polarity items, and other kinds of evaluative language. This pattern is expected under the pragmatic view we have proposed here. As Harris \& Potts (2009) discuss for appositives and expressives, perspective shift of this sort is a risky communicative strategy since the addressee may fail to understand the speaker's intended shift. The use of evaluative and other perspectival language in the denials mitigates this risk.

In contrast, if lack of speaker commitment were simply part of the semantics, bare denials ought to be perfectly natural, as they are with embedding verbs like say and hear. While we do not have access to systematic data of this sort, we note that nearly all attested examples have such elements, regardless of whether they were the result of elicitation, introspection, or natural speech. Furthermore, Mortelmans's (2000) corpus study of German sollen claims that speaker skepticism must be overtly marked, but that "this possibility is in practice not very frequently made use of". Finally, Koring (2013) reports the following contrast for Dutch schijnen:

\section{a. Dutch}

(Koring 2013: 50)

\#Anneloes schijnt thuis te zijn, maar dat is niet zo. Anneloes seems home to be but that is not so 'Anneloes is said to be at home, but she's not.'

7 We will refine this characterization somewhat in $\$ 4$, in particular about the question of what we mean by the willfully vague "assert in some sense" here. 


\section{b. Dutch}

(Koring 2013: 49)

Anneloes schijnt thuis te zijn, maar ik geloof er niets van.

Anneloes seems home to be but I believe there nothing of

'I've heard that Anneloes is at home, but I don't believe it.'

One further such aspect of the form denials take which is worth considering is their prosody. Previous literature does not report such information consistently, but we do find claims in several languages that prosody can play an important role in distancing the speaker's perspective from that of the reporter. For example, Schwager (2010) claims that when the Tagalog reportative daw is stressed, "the neutral report is lost and the speaker expresses doubt as to the truth of the prejacent". Valenzuela (2003) similarly claims for the Shipibo-Konibo reportative -ronki that "sarcastic" denials of the reportative proposition are possible with "marked intonation" among other means.

While denials are consistently possible given sufficient evaluative language and context, we must also stress that in the absence of such rich context, reportatives are typically used in apparently veridical ways. ${ }^{8}$ Faller (2007) discusses this at length for the Cuzco Quechua reportative -si, exemplified in (20). The speaker's commitment, of course, may still be weaker than if she had personally witnessed the blood going to Lima, but the speaker nonetheless does not show any sign of doubting the reporter and indeed the purpose of the utterance in the discourse is simply to add more detail about the sick individual's status.

Cuzco Quechua

(Faller 2007: 6)

a. Qusqu-pi hospital-pi ka-sha-n ...

Cuzco-LOC hospital-LOC be-PROG-3

'She is in Cuzco in [the] hospital ...'

b. Lima-man-raq- si yawar-ni-n-pis ri-n.

Lima-ILLA-CONT-REP blood-EUPH-3-ADD go-3

'Her blood even went to Lima.'

In this section, we have argued that the deniability of reportative evidentials is due not to an exceptional conventional semantic contribution, but to pragmatic perspective shift. Beyond explaining the forms that denials take, this approach explains why reportatives allow for this possibility but other evidentials do not. At the same time, since the reportative does not play a compositional role in the account (but only contributes indirectly by raising the salience of the reporter), we might

8 It should be noted that some languages do additionally have morphemes/constructions which indicate a reportative information source and appear to encode the speaker's doubt (e.g., Finnish muka, the so-called 'dubitative' in Bulgarian). We leave investigation of such elements to future work. 
On the exceptional status of reportative evidentials

worry that the account would predict that we should indeed find denials with other evidentials given a rich enough context. However, while this may be so in principle, it is important to note that all other evidentials besides reportatives do not simply lack a perspectival agent, but in fact explicitly invoke the perspective of the speaker. For example, an ABDUCTIVE INFERENTIAL evidential specifically references the inferences and perceptions of speaker (similarly for DIRECT and CONJECTURAL evidentials). Drawing again on the parallel with appositives and expressives, nonreportative evidentials are akin to instances of these elements within the scope of a first-person attitude report, and therefore ought to be quite resistant to perspective shift.

\subsection{Evidence from Bulgarian and Turkish}

Thus far, we have considered evidentials whose use is limited exclusively to contexts where the information source is reportative. In some languages, however, a single evidential form is used for both reportative and abductive inferential information sources, as illustrated in (21-22) for the evidential perfects in Bulgarian and Turkish, respectively.

(21) Bulgarian

Maria svirela na piano.

Maria play.INDIR on piano

'Maria plays the piano, [I heard/inferred].'

a. $\checkmark$ Reportative context: You and your sister were out of touch for a couple of years. Today she calls you on the phone to catch up. She tells you that her daughter Maria plays the piano. Later, you tell your husband.

b. $\checkmark$ Inferential context: You and your sister were out of touch for a couple of years. Today you visit her for the first time. As she shows you around her apartment, you see that there is a piano in her daughter Maria's room. You infer that Maria plays the piano. Later, you tell your husband.

(22) Turkish

(Şener 2011: 12)

Usain bolt koş-muş.

Usain Bolt run-INDIR

'It was reported to the speaker that/speaker inferred that Usain Bolt ran.'

a. $\checkmark$ Reportative context: The news on TV relating to the Beijing Olympics report Usain Bolt's run (i.e. information gained through third parties).

b. $\boldsymbol{V}$ Inferential context: Usain Bolt is giving a TV interview, all sweaty and tired right after he runs the 100 meter race. The speaker infers what 
the proposition is describing from the observable evidence, which is Usain Bolt looking tired.

Under the pragmatic account we have proposed, then, the prediction for denials with these forms are quite clear. In contexts which make salient a reportative information source - and therefore an alternative perspective - denials should be possible (given sufficient perspectival language). In contexts which make salient only an inferential information source, denials should not be possible since no alternative perspective is salient. These predictions are borne out, as shown by and Smirnova (2013) for Bulgarian and Şener (2011) for Turkish:

\section{Bulgarian}

(Smirnova 2013: 29, 34)

a. $\checkmark$ Reportative context: Your best friend, Ivan, has to work hard to support his family. His wealthy uncle died but did not leave him any money. When you speak on the phone with your former classmate, she tells you that Ivan had inherited millions from his uncle. You know that this is not true:

Ostavil mu milioni! Ta tojpuknata stotinkane mu e leave.INDIR him millions EMPH he crunched cent NOT him be.3sg.PRES ostavil.

leave.PERF.PLE

'He left him millions, [I hear]! He didn't leave him a red cent.'

b. \# Abductive inferential context: When you discovered a chapter of an unauthored manuscript in Maria's study, you inferred that Maria is writing a book. Later you learned that it is Maria's sister who is writing the book. When one of your friends asks you what Maria does, you say: \#Maria pišela kniga. Vsǎštnost, tova ne e taka. Maria write.INDIR book in.fact it NOT be.3sg.PRES so '\#Maria is writing a book, [I inferred]. In fact, it is not true.'

(24) Turkish

Sinan bisiklet-ten düş- müş ama gerçekte öyle birşey yok.

Sinan bike-ABL fall-INDIR but actually like nothing exists

'It is reported to the speaker that Sinan fell off the bike, but in fact nothing like that happened.'

a. $\checkmark$ Reportative context: Seda tells Ayşe (the speaker) that Sinan fell off the bike.

b. \# Abductive inferential context: Seda sees Sinan getting up from the ground with his bike and his backpack spread around. Although Seda hasn't see Sinan fall, she infers that he has fallen off the bike. 
On the exceptional status of reportative evidentials

While such data are expected on our pragmatic account of RE, a semantic account, it seems, must instead posit an otherwise covert ambiguity (as Smirnova (2013) and Şener (2011) do for Bulgarian and Turkish respectively). Beyond being less parsimonious, such an approach again begs the question of why the reportative allows for denials while the abductive inferential does not.

\subsection{Are there really any counterexamples?}

As noted in $\S 2.2$, previous literature has regarded RE as a parameter of crosslinguistic variation rather than a consistent pattern. The main reasons for this are claims that have been made for three languages of the Pacific Northwest: St'át'imcets (Matthewson et al. 2007), Gitksan (Peterson 2010), and Nuu-chah-nulth (Waldie, Peterson, Rullmann \& Mackie 2009). In particular, these authors claim that reportatives in these languages do commit the speaker to at least the possibility that the scope proposition holds, i.e. that reportatives in these languages do not violate the baseline conception semantically or pragmatically. On closer inspection, however, there is reason to doubt that these languages are in fact exceptions to the robust cross-linguistic pattern shown in $\$ 2.2$.

First, these authors make clear that they are in fact testing a subtly different hypothesis than the one considered here: whether it is infelicitous for a speaker to assert $p_{\text {REP }}$ if $s /$ he knows $p$ is false. Denials of the sort in (5-8) are regarded as particular instances of this larger pattern, but many of the examples given by these authors, as in (25), differ from the cases we have seen above:

Gitksan

(Peterson 2010: 127)

Context: You know John was at work yesterday [It is apparently known that John cans fish for fun when not at work rather than that he works in a fish cannery].

\#si-hon= gat $=$ it John k'yoots.

CAUS-fish=REP=PND John yesterday

'[I heard] John canned fish yesterday.'

Unlike (5-8), no perspectivally-rich environment is established in the context and nothing in the utterance serves to differentiate the speaker's perspective from the reporter's. In particular, the speaker's private knowledge/belief regarding $p$ (as stated in the context) ought to play no role unless there is reason to believe that this knowledge is somehow publicly available. Such examples are in fact expected under the pragmatic account given here and therefore do not give evidence supporting the claim of cross-linguistic variation. Only in St'át'imcets do we in fact find an

infelicitous utterance of the form ' $p_{\mathrm{REP}}$, but $\neg p$ ' given in support of this broader 
AnderBois

generalization, given in (26). ${ }^{9}$

(26) St'át'imcets

(Matthewson et al. 2007: 22)

Context: You had done some work for a company and they said they put your pay, \$200, in your bank account, but actually, they didn't pay you at all. \#Um'-en-tsal-itás $\quad$ ku7 i án'was-a xetspqiqen'kst táola, give-DIR-1SG.OBJ-3PL.ERG REP DET.PL two.EXIs hundred dollar t'u7 aoz kw s-7um'-en-tsál-itas ku stam'.

but NeG Det Nom-give-DIR-1SG.OBJ-3PL.ERG DET what

'\#[reportedly] They gave me $\$ 200$, but they didn't give me anything.'

While further empirical work is certainly needed, there are two reasons to doubt that this example in fact reveals a cross-linguistic difference in the semantics of reportatives. First, nothing in the glossing of this example indicates that there is any evaluative/perspectivally-charged language in the denial sentence. Recalling the Dutch data in (19), then, it may simply be that (26) fails to adequately convey the disconnect between the speaker's and reporter's perspectives, similar to (19a) rather than (19b) and the other attested denials.

Second, St'át'imcets has been claimed by Lyon (2009) to (quite surprisingly) lack perspective shift in a different case: verbal irony. Beyond noting the apparent absence of verbal irony in texts, Lyon constructs scenarios like (27) and claims that speakers consistently reject them in favor of more literal alternatives, e.g., 'Here is your thing which may or may not actually be a cup'.

St'át'imcets Lyon (2009)

Context: Participant A is visiting at his friend B's house to have coffee. B only has one cup and one bowl. B hands A a bowl of coffee and says:

\#Nilh ti7 ti zaw'áksten-sw=a.

FOC DEM DET cup-2SG.POSS=EXIS \#'Here's your cup!'

It seems plausible, then, that whatever more general linguistic and/or cultural aspects of perspective shift explain these observations might also explain the infelicity of (26). This is especially so since Matthewson et al. (2007) report that unprompted - speakers were explicitly comparing the utterance in question to a more literal example with a lexical verb glossed as 'say' in place of the reportative.

To summarize, we cannot at present rule out the possbility that the reportatives in St'át'imcets differ semantically in ways relevant for RE. However, in light of

9 Peterson (2010) purports to provide such an example for Gitksan (his example 3.63), but the example appears to involve a lexical verb glossed as 'hear' without the reportative =kat appearing at all. The infelicity of such an example is itself quite unexpected given the gloss, but in any case the example therefore does not bear on the present issue. 
On the exceptional status of reportative evidentials

the analysis proposed here and the cross-linguistic uniformity seen outside of the Pacific Northwest, there is ample reason to believe that either (i) examples with more evaluative language/perspectivally rich context will reveal a greater degree cross-linguistic uniformity than claimed in current literature, or (ii) any variation that does exist is variation in (the use of) pragmatic perspective shift itself and not something specific to the semantics of reportatives.

\section{Illocutionary evidentials contribute asymmetric assertions}

Thus far, we have argued that a variety of facts about RE cross-linguistically are best explained under an account based on pragmatic perspective shift. Having done so, we now revisit the question of what the semantics of reportatives looks like. In particular, we will propose an illocutionary semantics for declaratives which is constant across DiRECT, REPORTATIVE, and ABDUCTIVE INFERENTIAL evidentials ${ }^{10}$ and therefore demonstrates that the exceptionality of reportatives is due to the kind of information source they encode, rather than their compositional semantics. We focus here on socalled "illocutionary" evidentials (see Faller 2006, Matthewson et al. 2007, Murray 2010 for discussion of these two types of evidentials) since several existing accounts of "epistemic" evidentials such as Izvorski 1997, Matthewson et al. 2007 already do not build RE into the reportative's meaning. ${ }^{11}$

Since we are restricting our attention to declaratives here, our starting point is Stalnaker's (1978) well-known notion of Common Ground (CG). In Stalnaker's view, the CG is the set of propositions which "the speaker is disposed to act as if he assumes or believes that the proposition is true, and as if he assumes or believes that his audience assumes or believes that it is true as well". That is, while the CG is a basis for joint action in the conversation, it may diverge from speaker beliefs (a point discussed far more explicitly in Stalnaker 2002).

At the same time, we do clearly nonetheless keep track of what other speakers believe, or at least what they are publicly committed to believing. And more importantly, a number of recent works, starting with Gunlogson's (2001) analysis of rising declaratives like It's raining? have argued that a variety of constructions make conventional reference to the Discourse Commitments, $\mathbf{D C}_{x}$, of each individual speaker $x$, as distinct from the CG. Following these authors, then, we assume that a discourse context determines an ordered triple as follows:

10 The analysis we propose does not extend straightforwardly to so-called 'conjectural' evidentials, which show a quite different kind of exceptionality in several languages: utterances of the form $\operatorname{CONJ}(p) \wedge \operatorname{CONJ}(\neg p)$ are felicitous, but denials with other evidentials or no evidential are not.

11 It should be noted that apparent variation in RE is one of the pieces of data used by these authors to motivate this distinction. However, since as discussed in $\$ 2.2$, denials are attested with putatively epistemic reportatives in Bulgarian, Dutch, German, Japanese, and Turkish, it seems clear that this data does not distinguish the two classes. 
Discourse components: $\left\langle X, \mathrm{CG}_{X},\left\{\mathrm{DC}_{x} \mid x \in X\right\}\right\rangle$

While this basic setup is similar to Gunlogson 2001, Farkas \& Bruce 2010 and a number of other recent works, we differ in that we take both $\mathbf{C G}_{X}$ and $\mathbf{D C} \mathbf{C}_{x}$ to be primitives. The motivation for this is to reflect the fact that given Stalnaker's characterization of the CG as a basis for joint action, a speaker and hearer might well mutually decide to presume a given proposition is true and act accordingly even if neither is entirely committed to this being so, publicly or privately.

An ordinary assertion with no evidential marking, then, targets both of these elements. The essential effect of an assertion is to propose an update to the our shared store of assumptions, the CG. That assertions merely propose CG updates has been emphasized in general in a number of recent works (e.g., Groenendijk \& Roelofsen 2009, Farkas \& Bruce 2010) and in connection with evidentials specifically by Murray (2010). Since $\mathbf{D C}_{x}$ is individually anchored, it can be updated free of negotiation. The resultant picture for an assertion, then, is the following:

(29) An ordinary assertion by discourse participant $A$ with propositional content $p$ :

a. Adds $p$ to $\mathrm{DC}_{A}$.

b. Proposes to add $p$ to $\mathrm{CG}_{\{A, B\}}$ on the basis of (29a), subject to acceptance or denial by $B$.

We can call an ordinary assertion symmetrical since the propositions referred to in (29a) and (29b) are the same. A declarative with an illocutionary evidential, we claim, is used to make an asymmetric assertion:

(30) An evidential assertion by discourse participant $A$ with propositional content $p$ and evidence type EVID:

a. $\operatorname{Adds} \operatorname{Evid}(p)$ to $\mathrm{DC}_{A}$.

b. Proposes to add $p$ to $\mathrm{CG}_{\{A, B\}}$ on the basis of (29a), subject to acceptance or denial by $B$.

The speaker publicly commits herself to having a certain type of evidence for $p$, but avoids having to make a public commitment to $p$ itself. Although the speaker does not publicly commit to $p$, the conventional effect of the evidential assertion is to propose that the conversational participants should continue the conversation acting as though $p$ were true. Despite the lack of a public commitment to $p$, a cooperative, rational speaker nonetheless should not make such an assertion if they believe $p$ to be false (i.e. proposing to add false information to the $\mathrm{CG}$ would violate the Maxim of Quality). The evidential strategy is, therefore, a face-saving strategy of sorts, allowing the speaker to avoid taking on public commitments for things other 
On the exceptional status of reportative evidentials

than their subjective information. This picture thus far is constant across evidence types, including reportatives, where the existence of reportative evidence that $p$ is added to $\mathrm{DC}_{A}$ and the speaker proposes to add $p$ to the $\mathrm{CG}$ (recall the typical use of reportative exemplified in (20)).

Where reportatives differ, then, is not at the level of semantics, but rather in facilitating pragmatic perspective shift. Cases of RE, like (31), have the same conventional contribution, but differ in that the proposal is attributed to the reporter rather than the speaker herself, as described in (32).

\section{Cheyenne}

(Murray 2010: 58)

$$
\text { É-hótäheva- sėstse Floyd naa oha é-sáa-hótảhévá-he- } \varnothing \text {. }
$$

3-win-REP.3sg Floyd and CNTR 3-neg-win-MOD ${ }_{a}$-DIR

'Floyd won, I hear, but I'm certain he didn't.'

a. Adds $\operatorname{Evid}(p)$ to $\mathrm{DC}_{A}$.

b. The speaker points out that the reporter would propose to add $p$ to $\mathrm{CG}_{\{A, B\}}$ on the basis of (29a), subject to acceptance or denial by $B$.

Just as with non-speaker-oriented appositives and epithets, the content in (32b) would - semantically - be attributed to the speaker, but given the perspectivally-rich environment need not be. This parallel highlights the sense in which RE is a risky communicative strategy: if the addressee fails to pick up on the speaker's intended perspective shift, she will take the speaker's intent to be to add $p$ to the $\mathrm{CG}$, precisely the opposite of what the speaker in fact intends.

\section{Conclusion}

In this paper, we have argued that the ability for a single speaker to deny the scope of a reportative is widespread across languages, but typically makes crucial use of evaluative and other perspectivally-charged language. Previous accounts of this exceptional behavior for reportatives have attributed this possibility to their compositional semantics. Given the empirical findings of the current study, we have instead argued for an account where the potential for reportative denials arises from the pragmatics of perspective shift. In addition to making better cross-linguistic predictions (e.g., the behavior of indirect evidentials in Bulgarian and Turkish), the approach provides a principled explanation for why reportatives consistently show this behavior while other evidentials do not. The semantics of reportatives of course still differ across languages in a great many ways which we have not accounted for here (e.g., readings in interrogatives and imperatives, embeddability, projection). However, we hope to have made the case that reportative exceptionality is not one of these parameters of variation, and being due to pragmatic perspective shift, is therefore not part of the data that semantic analyses of reportatives must account for. 
AnderBois

\section{References}

Aikhenvald, Alexandra. 2004. Evidentiality. Oxford University Press.

Amaral, Patricia, Craige Roberts \& E. Allyn Smith. 2007. Review of The Logic of Conventional Implicatures. Linguistics and Philosophy 30. 707-749.

Brody, Jill. 1988. Incipient literacy: From involvement to integration in tojolabal maya. Oral Tradition 3(3). 315-352.

Davies, Mark. 2008-. The corpus of contemporary American English (COCA): 400+ million words, 1990-present. Available online at http: //www . americancorpus .org.

Déchaine, Rose-Marie, Clare Cook, Jeffrey Muehlbauer \& Ryan Waldie. 2014. (de-)constructing evidentiality. Ms. UBC, online at http://ling. auf . net/lingbuzz/002089.

Dixon, R.M.W. 2003. Evidentiality in Jarawara. In Alexandra Aihkenvald \& R.M.W. Dixon (eds.), Studies in Evidentiality, 165-187. John Benjamins.

Faller, Martina. 2002. Semantics and pragmatics of evidentials in Cuzco Quechua: Stanford dissertation.

Faller, Martina. 2006. Evidentiality below and above speech acts. Ms. Univ. of Manchester, online at http://semanticsarchive.net/Archive/GZiZjBhO/

Faller-evidentiality.above.below.pdf.

Faller, Martina. 2007. The Cusco Quechua reportative evidential and rhetorical relations. Linguistiche Berichte 14. 223-252.

Faller, Martina. 2012. Evidential scalar implicatures. Linguistics and Philosophy 35(4). 285-312.

Farkas, Donka \& Kim Bruce. 2010. On reacting to assertions and polar questions. Journal of Semantics 27(1). 81-118.

Groenendijk, Jeroen \& Floris Roelofsen. 2009. Inquisitive semantics and pragmatics. In Jesus Larrazabal \& Larraitz Zubeldia (eds.), Proceedings of SPR 09, 41-72. Universidad del País Vasco.

Gunlogson, Christine. 2001. True to form: rising and falling declaratives as questions in English: UCSC dissertation.

Harris, Jesse A. \& Christopher Potts. 2009. Perspective-shifting with appositives and expressives. Linguistics \& Philosophy 32(6). 523-552.

Izvorski, Roumyana. 1997. The present perfect as an epistemic modal. In Aaron Lawson (ed.), Proceedings of SALT 7, CLC Publications.

Kim, Juning. 2012. Korean evidentials in discourse: University of Texas at Austin dissertation.

Koring, Loes. 2013. Seemingly similar: Subjects and displacement in grammar, processing, and acquisition: Utrecht University dissertation. 
On the exceptional status of reportative evidentials

Krawczyk, Elizabeth. 2012. Inferred propositions and the expression of the evidence relation in natural language: evidentiality in Central Alaskan Yupik Eskimo and English: Georgetown dissertation.

Laughren, Mary. 1982. A preliminary description of propositional particles in Warlpiri. In Stephen Swartz (ed.), Work Papers of the Summer Institute of Linguistics, Australian Aborigines Branch A 6, 129-163. SIL.

Lyon, John. 2009. Grammatical restrictions on ironic interpretations in St'át'imcets. Ms. UBC.

Matthewson, Lisa, Henry Davis \& Hotze Rullman. 2007. Evidentials as epistemic modals: evidence from St'átimcets. Linguistic Variation Yearbook 7. 201-254.

McCready, Eric \& Norry Ogata. 2007. Evidentiality, modality and probability. Linguistics and Philosophy 30. 147-206.

Mortelmans, Tanja. 2000. On the 'evidential' nature of the 'epistemic' use of the German modals müssen and sollen. In Johan van der Auwera \& Patrick Dendale (eds.), Modal verbs in Germanic and Romance languages, 131-148. John Benjamins.

Murray, Sarah. 2010. Evidentiality and the structure of speech acts: Rutgers dissertation.

Peterson, Tyler. 2010. Epistemic modality and evidentiality in Gitksan at the semantics-pragmatics interface: University of British Columbia dissertation.

Potts, Christopher. 2005. The Logic of Conventional Implicatures. Oxford University Press.

Schenner, Mathias. 2010. Evidentials in complex sentences: foundational issues and data from Turkish and German. In Tyler Peterson \& Uli Sauerland (eds.), Evidence from Evidentials, 183-220. University of British Columbia Working Papers in Linguistics.

Schwager, Magdalena. 2010. On what has been said in Tagalog. In Tyler Peterson \& Uli Sauerland (eds.), Evidence from Evidentials, 221-246. University of British Columbia Working Papers in Linguistics.

Şener, Nilüfer. 2011. Semantics and pragmatics of evidentials in Turkish: UConn dissertation.

Smirnova, Anastasia. 2013. Evidentiality in Bulgarian: Temporality, epistemic modality, and information source. Journal of Semantics 30(4). 479-532.

Stalnaker, Robert. 1978. Assertion. In Peter Cole (ed.), Syntax and Semantics, vol. 9, 315-332. Academic Press.

Stalnaker, Robert. 2002. Common ground. Linguistics and Philosophy 25. 701-721. Thomas, Guillaume. 2014. Embedded imperatives in Mbyá. In Hsin-Lun Huang, Ethan Poole \& Amanda Rysling (eds.), Proceedings of NELS 43, 181-194. GLSA.

Tonhauser, Judith. 2013. Reportative evidentiality in Paraguayan Guaraní. In Hannah 
Greene (ed.), Proceedings of SULA 7, 189-204. GLSA.

Valenzuela, Pilar. 2003. Evidentiality in Shipibo-Konibo, with a comparative overview of the category in other Panoan languages. In Alexandra Aihkenvald \& R.M.W. Dixon (eds.), Studies in Evidentiality, 33-61. John Benjamins.

Waldie, Ryan, Tyler Peterson, Hotze Rullmann \& Scott Mackie. 2009. Evidentials as epistemic modals or speech act operators: testing the test. Handout from WSCLA.

Wilkins, David. 1989. Mparntwe Arrernte (Aranda): studies in the structure and semantics of grammar: Australian National University dissertation.

Willett, Thomas. 1988. A cross-linguistic survey of the grammaticalization of evidentiality. Studies in Language 12(1). 51-97.

Zubeldia, Larraitz. 2012. 'omen', a non-modal evidential particle contributing to the truth-conditions of the utterance. Slides from talk at The Nature of Evidentiality at Leiden University.

Scott AnderBois

Brown University

Dept of Cog. Ling. and Psych. Sci. (CLPS)

Box 1821

190 Thayer Street

Providence, RI 02912

scott_anderbois@brown.edu 